\title{
Assessment of Solid Waste Management in the Islamic City of Marawi, Philippines
}

\author{
Asnawi Dataman, Ruben F. Amparado Jr., Edgardo Aranico, Mark Anthony J. Torres, and Cesar G. \\ Demayo, Member, IACSIT
}

\begin{abstract}
This study was conducted to determine some issues and concerns of solid waste management in the city of Marawi, Philippines. Interviews were conducted on key informants.The respondents of this study were five (5) City Government Officials (Secretary, Office of the City mayor, City Planning and Development Officers, City General Services Officers, SP Representative-Committee on Environment, SP Secretary), and two (2) key officials/representatives from DOH and DENR. They were selected because of their direct involvement and participation in the implementation of the Solid Waste Management Program. This study used the descriptive-qualitative research method. Results show that theoretically the city government has the necessary mechanisms of how solid wastes be managed in the city but the implementation of the ecological waste management program as mandated by law is unsuccessfull. Several reasons are attributed to this - lack of personnel, funds, and also to the undisciplined behavior of the Maranaos in their waste disposal.
\end{abstract}

Index Terms-Solid waste, Islamic city, non-government organization.

\section{INTRODUCTION}

The United Nations and its member states recognize the powerful development role that cities play as focal points for investment, communication, commerce, production and consumption. It is for this reason that cities lure immigration since many thought that in the cities one can seek a better life. Many problems however result from the influx of people into cities especially on solid wastes [1].

In the Philippines, former Philippine President Gloria Macapagal Arroyo signed into law Republic Act (RA) 9003 which requires and directs national and all Local Government Units (LGU's) nationwide to establish an ecological solid waste management program within their jurisdictions and provide the necessary institutional mechanisms to attain its objectives [2] This act is the most comprehensive piece of government legislation and its enforcement to the LGU's emphasizes the importance of minimizing waste by using techniques as recycling, resource recovery, reuse, and composting [3] It is in this context that a study was conducted

Manuscript received August 31, 2012; revised October 26, 2012. This work was supported in part by the Department of Science and Technology (DOST) graduate scholarship program.

Asnawi Dataman is with the Department of Environment and Natural Resources-ARMM, MSU-Iligan Instite of Technology, Iligan City, Philippines (email:asnawidataman@yahoo.com).

Cesar G. Demayo, Mark Anthony J. Torres, Ruben F. Amparado, Jr. and Edgardo C. Aranico are with the Department of Biological Sciences, College of Science and Mathematics, MSU-Iligan Institute of Technology, Iligan City, Philippines. (e-mail: cgdemayo@gmail.com; torres.markanthony@gmail.com; ruben_amparado@yahoo.com; ecadbs_csmmsuiit@ ahoo.com). in a city where great concern is raised since it is situated in one of the largest and threatened lakes in the Philippines, the Lanao Lake (Fig. 1, 2).

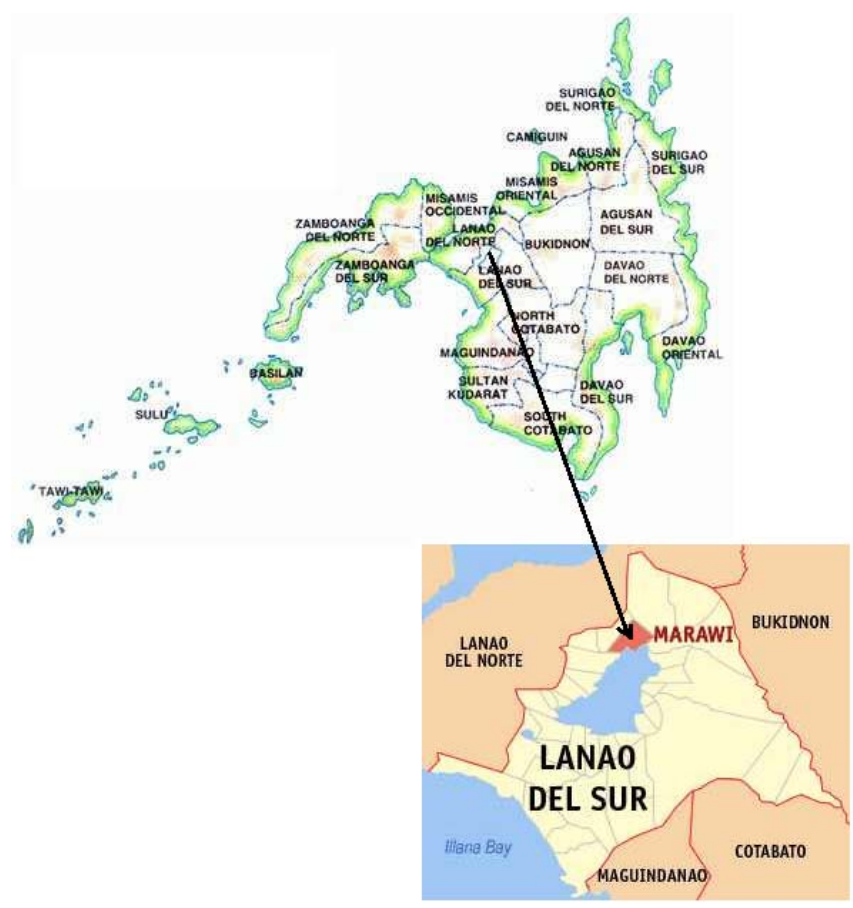

Fig. 1. Map of Manao del Sur where Marawi City is situated.

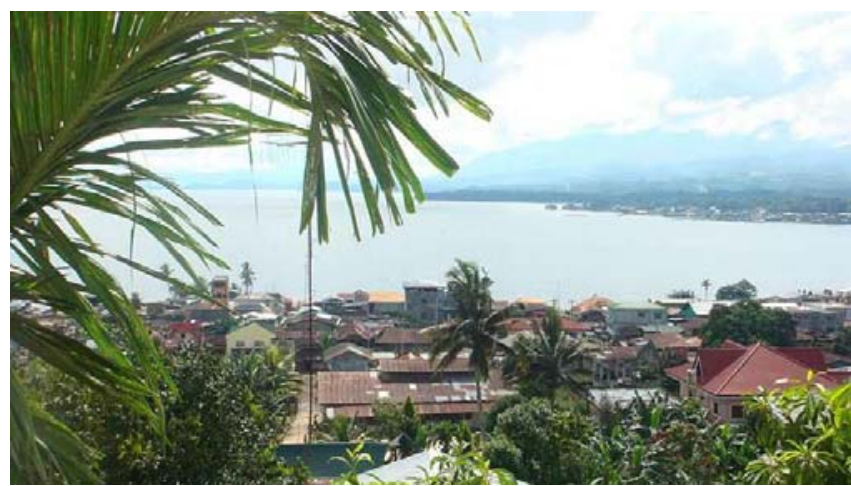

Fig. 2. Marawi City is situated along the Lake Lanao.

The Islamic City of Marawi is the capital city of the province of Lanao del Sur on the island of Mindanao in the Philippines. The city has exhibited a higher level of growth both in terms of population and income as compared to the rural areas. The dynamic trade and commerce in the city has contributed to the rapid increase in its population which brought about several issues and problems such as health and sanitation, garbage collection and disposal (Fig. $3,4,5$ ), environmental and ecological problems, poor housing condition, congestion, inadequacy of infrastructure facilities 
and inefficient delivery of basic services, ill-equipped personnel handling the garbage collection system and the absence of a permanent dumpsite or sanitary landfill. These are some major concerns which contributed to the worsening solid waste management problems in the city. One of the city officials' primary concerns is to provide and ensure cleanliness to protect the health of its people. Thus, the program of the City government of Marawi in the collection and disposal of waste has to be comprehensive and integrated so that it can address its solid waste in a holistic manner, as contained in the city code numbered 2360 [4] approved on November 25, 2003. A visit to the city will show it is suffering from garbage problems. One can find garbage anywhere scattered in the streets, waterways, canals and even major roads (Figs. 3, 4, 5).

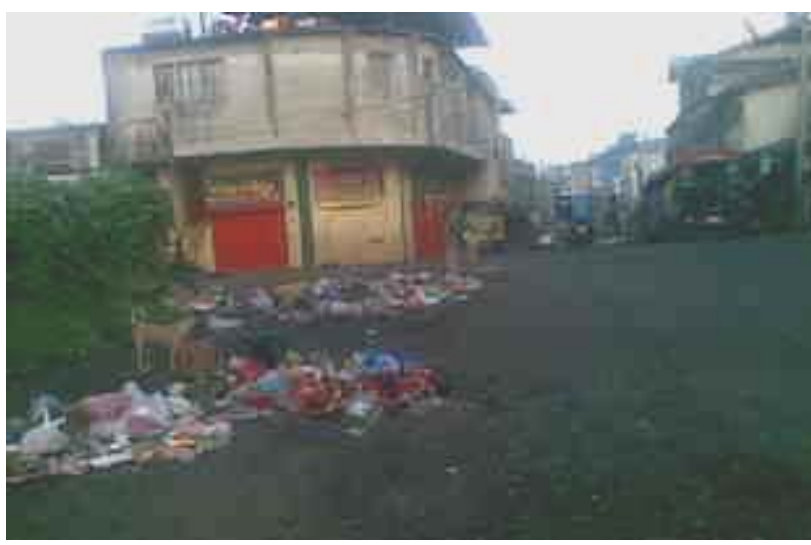

Fig. 3. Garbage are common sight in the city.

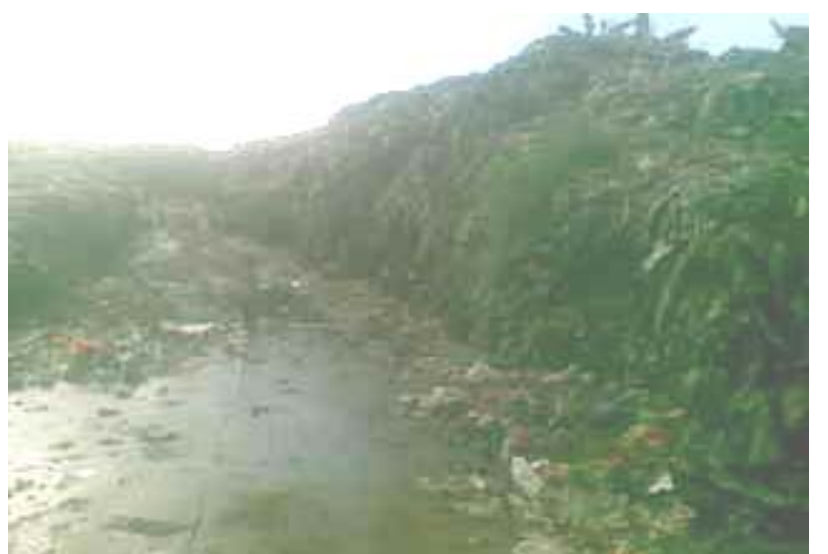

Fig. 4. Mounds of garbage in the city temporary dumpsite.

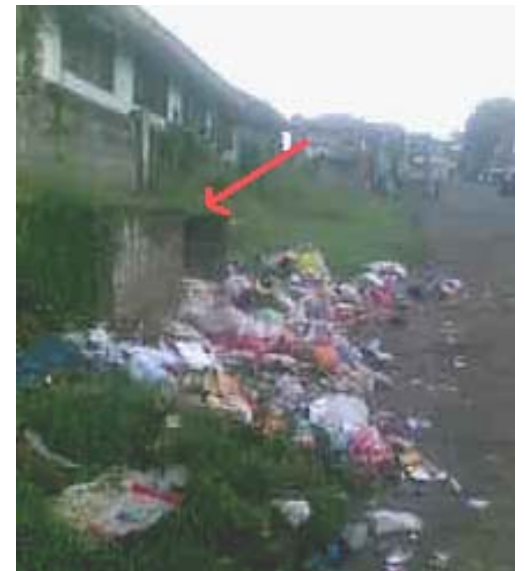

Fig. 5. Garbage are thrown outside the old and destroyed receptacles.

This study assessed the Solid Waste Management Program
(SWMP) of the city in the areas of manpower, equipment, technical and financial support, and the implementation of SWMP management functions such as planning, monitoring, people's participation and law enforcement and determines the effectiveness of the SWMP in terms of waste collection and waste disposal.

\section{MethodOlOGY}

The respondents of this study were five (5) City Government Officials (Secretary, Office of the City mayor, City Planning and Development Officers, City General Services Officers, SP Representative-Committee on Environment, SP Secretary), and two (2) key officials/representatives from DOH and DENR. They were selected because of their direct involvement and participation in the implementation of the Solid Waste Management Program. This study used the descriptive-qualitative research method. An interview guide was prepared containing questions pertaining to the activities of the City Government in the areas of manpower, equipment, technical support, and financial support as far as solid waste management program is concerned. Furthermore, questions on various management functions such as planning, monitoring, people's participation, and law enforcement, effectiveness of the program in terms of waste collection and disposal. Assessment of problems encountered during implementation especially on the effectiveness of the program in waste collection and waste disposal.

Field observations during assembly meetings, consultation dialogues, orientation and seminars or trainings were also done. Observations on the Solid Waste Management Program during the quarterly meetings and general orientation by the City Government were noted. A review of official documents such as Ordinances, Solid Waste Management Plan, and Comprehensive Land Use Plan for 30 years, and the profile of Marawi City were made.

\section{RESUlts}

Based from the interviews of key informants, the following information was generated:

\section{A. Manpower}

There were 75 personnel who were directly involved on the Implementation of Solid Waste Management Program in Marawi City. The distribution of work assignments were twenty five (25) street sweepers, two (2) foreman, one (1) back hoe operator, three (3) drivers, and the rest of the personnel were stationed in the SWM office as staff including those detailed in the Office of the General Services. They performed eight (8) hours a day in seven (7) days by cleaning and sweeping the main thoroughfares. For places found in the populated areas, the conduct of street sweeping of roads varied from two (2) to three (3) days a week. Few personnel were holding permanent status and most of the street sweepers were contractual workers. The street sweepers were supervised by their respective foreman and obliged to submit reports every month through the filling up of prescribed form. 


\section{B. Equipment}

The City government of Marawi have procured and provided the SWM Program of only one old and dilapidated but in good running condition Dump truck and three (3) Mini dump trucks donated by the City Engineering Office (Fig. 6). Working paraphernalia including first aid kits intended for the use of street sweepers, drivers, foreman, and other personnel were purchased every year by the city. Garbage receptacles were seen in different strategic places along the streets as storages of garbage from the residents. Some villages have put up their own Material Recovery Facility (MRF's) in order to cater to the segregation activities from the generated solid wastes. ACF, a non-government organization (NGO) facilitated the implementation of the said program by giving push carts for the street sweepers as well as "trisikads" (a human-driven tricycle) to be used by the village officials.

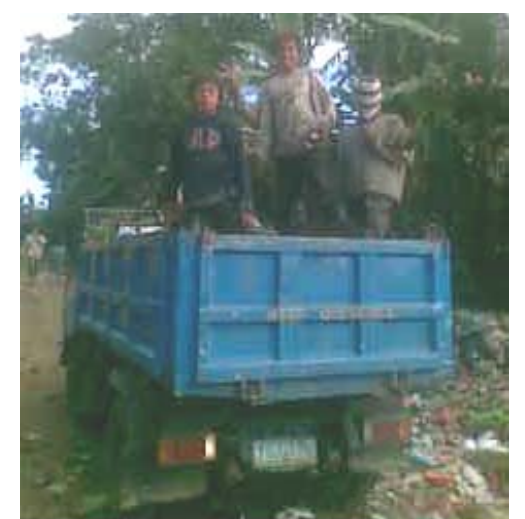

Fig. 6. Old and delapidated dumptruck used to haul garbage from the city.

\section{Technical Support}

The City government had sponsored human resources trainings for those officials and employees involved in managing the implementation of the Solid Waste Management Program of the city. All the workers in the field were obliged to attend trainings, seminar-workshops and fora even prior to their deployment in their respective area of assignments. The village officials and the entire constituency were invited for trainings and seminars sponsored by the City government with the technical assistance of the Action Against Hunger Foundation (ACF), an international non-government organization headed by an Italian National.

\section{Financial Support}

Financial funds coming from the City government were insufficient to support the program because they were limited only on information/education campaign, personal services, fuel, and operation maintenance of the dumpsites. The Sangguniang Panglungsod (SP) or city government can only enact legislations required by the National Solid Waste Management Commission (NSWMC) and extend their support by giving fund appropriations [5]. Acquisition of equipments, tools, and materials were taken from the budget from the approved financial funds of the city government.

\section{E. Planning}

The City Solid Waste Management Board serves as the planning and policy body. This board was created by virtue of Republic Act No. 9003 otherwise called the Ecological
Solid Waste Management Act of 2000 [3] anchored to R.A. 7160 known as the Local Government Code [6], and City Ordinance numbered 2360 named as Comprehensive Solid Waste Management Code [4]. This board was purposely created to assist and advise the city mayor regarding the formulation of policies and crafting of programs. The said body was chaired by the local chief executive and performs the duties/ responsibilities in the development of a Solid Waste Management Plan to ensure long term implementation in the city. The board is also tasked to recommend to the city government appropriate measures or proposals for franchise or build operate transfer agreements with duly recognized institutions in providing either exclusive or non-exclusive authority for the collection, transfer, processing, recycling or disposal of the city's solid wastes. The board coordinates the efforts of villages in the implementation of the City Solid Waste Management Plan. It is to be noted here that the proposed plan after having been deliberated by the body will be forwarded to the technical working group for analysis, synthesis, and evaluation and organize it to become a working document which will then be thoroughly checked and scrutined by the board before forwarding to the chairman for approval. Action planning was the regular activity conducted by the board for the city's short-term plan. This includes setting objectives, priorities, and targets at the operational levels of each activity. The city government had a planning process through the adoption of bottom-up approach to ensure that the formulated solid waste management plans was realistic and operational. This includes pre-consultations/ discussions at the village level being the lowest unit in the government in collaboration with all the various sectors before a full-blown city-wide planning will be pursued.

\section{F. Monitoring}

Three (3) groups were created as monitoring team of the program such as the technical working group, team from the Office of the General Services, and the Task Force Kalinisan. They monitor the established garbage pick-up point with properly labeled receptacle, practice of backyard composting, and gardens at the villages, the villages' compliance of deputizing sanitary officers of their law-enforcement activities, compliance of plans and activities including facilities availability, equipment readiness and technical knowledge, manpower resources competencies and load assignment of street sweepers, well-maintained clean "purok" or areas, green surroundings including "Tapat ko, Linisin ko” program, and establishment of village Material Recovery Facility (MRF).

\section{G. People's Participation.}

The proper administration of solid waste management is argued to enable the community to participate in the dynamics, through their contribution of waste reduction and minimization thus is being pushed. Some villages were reported to be very active in supporting the program in terms of practicing reduce, recycle, and re-use at the level of the households as a result of the hard work, information, and education campaign of the city government. There are however, those passive village officials where their residents 
have not been doing the proper management of solid wastes. Some of those caught were indiscriminately throwing garbage in creeks, canals, and rivers that resulted to clogging of waterways and have caused flooding in the city. The city government requires the villages to cooperate in this program and perform their duties in the implementation of the Solid Waste Management Program or village officials concerned will be sanctioned but implementation was not achieved.

\section{H. Law Enforcement}

There was only (1) itemized personnel assigned to the enforcement of Solid Waste Management Program in Marawi City supported with the sanitary division employees from the Office of the General Services. The city government produced warning signs posted in all public places including printed information materials provided to the people to follow. Sanitary inspectors were deputized in different villages in response to the call of law enforcement by the City government. Those who violate the provisions of the program will be fined, penalized or sanctioned or to render community service (PD 825) [7]. All cash penalties will be collected and remitted to the City treasurer's office.

\section{Discussion}

Based from the results of the interviews of key informants, in principle, the City government of Marawi's 12 pilot villages can administratively be able to manage their solid waste program based on manpower, equipment, technical and financial support. Considering the management functions by the officials through planning, monitoring, people' participation, and law enforcement, it can even be argued that the operation of this program will be ready for the full blown city wide implementation. However, the city remained dirty as there are a lot of uncollected garbage that can be seen anywhere. The large amount of uncollected garbage; improper waste segregation from the households; throwing of garbage anywhere especially in waterways and the irregular collection of garbage in the villages, the inadequacy of permanent receptacles in the streets and insufficient number of garbage trucks used for collection and transportation of garbage were the major concerns. The twenty five (25) personnel as street sweepers were not enough to cope with the task of sweeping the whole areas assigned to them. There is poor technical knowledge on the part of village officials including sanitary inspectors, officials and staff involved in managing the ISWMP. Added to these were the limited fund appropriated up to the village levels on all the activities lined-up in the ISWM Program. The regular absences of some members of the City Solid Waste Management Board hinder the formulation of long term plans and activities on the SWMP Implementation. Monitoring activity on the part of the city government is also ineffective because the stakeholders show some degree of dissatisfaction and there was continuous social opposition particularly those who lived near the identified dumpsite. Law enforcement was never effective as only one (1) personnel is assigned to do the job.

Problems on waste collection and waste disposal were the important aspects to be looked into by the city government specifically the segregation of waste into biodegradable and non biodegradable and the recycling of waste material. The city government cannot push through the zero - waste management because there were still no sanitary landfills or dumpsites. Therefore, problems on 3R's (reuse, recycle, and reduce) were not effectively communicated to the people and they needed more education of the village officials.

Another major issue in the solid waste management of the city is the behavior of the people. Behavior is considered a key cultural aspect that is embedded in people's way of life. There is a need to study the community's behavior on solid wastes. And changes require intensive, long-term and creative social marketing in the part of the city government by studying the demographic and cultural fiber of the community through immersions and capacity building activities (RA 9512) [8]. Studies have shown that not only the Maranao people of Marawi but most Filipinos perceive waste management as the responsibility of government and that public participation in waste management, especially in segregation at source, remains limited [9]. There is a need for the city for more extensive awareness- raising activities and training on ecological waste management together with stricter enforcement of the Law and local ordinances must be observed. Likewise, community empowerment and political will to resolve the problem should be enforced.

The problem of Marawi City is not an isolated case. The Philippines is facing big problems, even if this law on Ecological Solid Waste Management was approved several years back. Data from the National Solid Waste Management Commission shows that there are 677 open dumpsites, 343 controlled dumps, and 21 landfills in the country [5]. An additional 307 dump sites are subject for closure or rehabilitation plans but without definite schedules for enforcement [10]. More additional landfills are being proposed to be set up nationwide. Added to the concerns are that many cities do not have their own sites. To make the city government ensure the successful implementation and enforcement of the solid waste management law [11] to contribute largely in the country's development in general and tangibly reflected on peaceful well-being of local communities in particular[12], the success of the program cannot be achieved by the leader only nor a single group but rather for all the people who will act enthusiastically in attaining societal goal [13].

There are solutions however that is in place to improve the management of urban wastes in Marawi city by the City Government. The city recognize the fact that mismanagement of waste has serious environmental consequences: ground and surface water contamination, local flooding, air pollution, exposure to toxins, and spread of disease. The disposal dumpsites contain infectious material, thus threatening sanitation workers and waste-pickers. It is hoped that the Islamic City of Marawi can improve its management of urban wastes through the help of the city's Muslim religious sector, the Ulama. The religious group has committed to act in support of the local government's Integrated Solid Waste Management program in the context of a solid waste management (SWM) orientation which was specially conducted for the group last June 11, 2009 initiated by the City Government of Marawi and the Philippine 
Environmental Governance Project (EcoGov), a project of the U.S. Agency for International Development (USAID) in partnership with the Department of Environment and Natural Resources (DENR). Leaders from the ranks of the Aleem (religious leader who has good knowledge of Islam), and the city local government who participated in this event, have highlighted the principles of Islamic environmental management, culled from the environmental sourcebook $\mathrm{Al}$ Khalifa (The Steward) promoting environmental management in Muslim communities. This has been endorsed by the Assembly of the Darul Ifta of the Philippines. The program delves into the religious consciousness of Muslims in preaching that maintaining ecological balance is a duty of each Muslim, being God's khalifa (steward) on Earth. The program will include waste management in the topics of their weekly radio program for women, in the khutba (sermon during the Friday congregational prayer), and broadcast this to the children of the madrasah (Arabic schools, a building or group of buildings used for teaching Islamic theology and religious law, typically including a mosque)). The Muslim religious leaders gained an appreciation of proper waste management practices, such as waste segregation, composting, and reuse of materials. For the first time, concrete steps to these practices were demonstrated in their midst, which boosted their eagerness to share firsthand information to their community members and to initiate small-scale SWM programs in mosques and madrasah.

\section{ACKNOWLEDGMENT}

The authors would like to thank the City Government of Marawi especially the following Ms. Norhaya B. Ampang, Secretary, Office of the City Mayor, Engineer Macapanton A. Dianalan, General Services Officer, Mr. Baguindali Ambor, DENR Technical Personnel/representative, Engineer Villamor Bagumbaran, Planning Offices IV, City Planning and Development Office, Omar hassan "POGI” Lucman, SP Chairperson, Committee on Environment, Ms. Sarah Disomangcop, Head, Sanitation Division, City Health Office, Mr.Nasser Lala., SP Secretary, Mr. Baguindali Ambor, Chief, Solid waste Mgt., DENR-CENRO, Village Chairman Misbac Abdul of Dagduban, Mr. Nasser R. Lala Secretary to the Office of the Sangguniang Panlungsod, Mr. Baguindali Ambor, of DENR, CENRO-Marawi City, for the support provided the researchers and the Department of Science and Technology of the Philippines for the research funds.

\section{REFERENCES}

[1] United Nation Development Program (UNDP) Survey of 151 Cities of the World (1997). Urban Problems Remain Similar Worldwide. [Online]. Available: http://mirror.undp.org/magnet/Docs/urban/Maysur.htm.

[2] Republic Act No. 9003. Republic of the Philippines, Congress of the Philippines, Metro Manila, Eleventh Congress, Third Regular Session. [Online] http://emb.gov.ph/nswmc/pdf/iec/R.A.\%209003.PDF.

[3] A. De Guzman and J. Reyes, "Solid Waste Management: (Options and Solutions at the Local Level) Local Government Support Program (LGSP) Philippine-Canada 2003,” [Online]. Available: http://lgrc.dilg10.org/v2/KP/Gov/Service/solidwaste.pdf.

[4] Ordinance No. 2360, Comprehensive and Integrated Solid Waste Management Code of Marawi City, November 25, 2003.
[5] Programs of the National Waste Commission of the Philippines [Online]. Available: http://www.emb.gov.ph/nswmc.

[6] Republic Act (RA) No. 7160 "Local Government Code of 1991". [Online]. www.lawphil.net/statutes/repacts/ra1991/ra_7160_1991.html

[7] Presidential Decree (PD) No. 825 "Providing penalty for improper disposal of garbage and other Forms of Uncleanliness and for other purposes” (1975). [Online]. Available: www.lawphil.net/statutes/presdecs/pd1975/pd_825_1975.html

[8] Republic Act (RA) No. 9512, The Environmental Awareness and Education Act of 2008, (December 12, 2008). [Online]. Available: http://elibrary.judiciary.gov.ph/republic_acts.php?doctype=Republic \%20Acts\&docid=12329547271987714391.

[9] Environmental Problems in the Philippines. [Online] Available: http://imagineechoprojectswaste.blogspot.com/.

[10] Guidebook for Safe Closure of Disposal Sites. $-1^{\text {st }}$ Edition 2006, National Solid Waste Management Commission (NSWMC), Japan International Cooperation Agency (JICA), Quezon City: National Solid Waste Management Commission, 2006, pp. 81.

[11] Presidential Decree (PD) 1152 "The Philippine Environmental Code of 1977". [Online] Available: http://www.denr.gov.ph/laws-and-policies.html

[12] P. L. Padilla, "Strengthening Local Government administration and Accelerating Local Development” Local Government Center, UP-CPA and Asia Foundation, Philippines, 2003.

[13] F. M. Zulueta and D. B. Liwag, Social Problems and Issues in the Philippines, National Book Store series of 2001, National Book Store, Philippines.

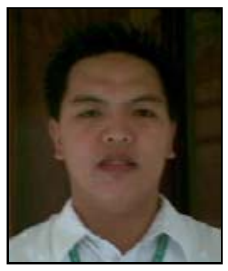

Asnawi Dataman Dataman is connected with the Department of Environment and Natural Resources-ARMM. He is pursuing the degree of MS in Environmental Science at MSU-Iligan Instite of Technology, Iligan City, Philippines. He has been involved in environmental research projects of Marawi City. (email:asnawidataman@yahoo.com).

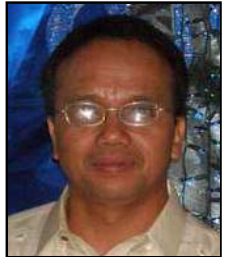

Ruben F. Amparado Jr. is Professor III of Biology, Department of Biological Sciences, College of Science \& Mathematics, MSU-Iligan Institute of Technology, Iligan City, Philippines. He is teaching courses in environmental science and sustainable development. His research is geared towards environmental ecotoxicology and management. (e-mail:ruben_amparado@yahoo.com).

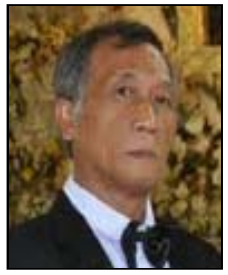

Edgardo Aranico is Associate Professor of Botany, Department of Biological Sciences, College of Science and Mathematics, MSU-Iligan Institute of Technology, Iligan City, Philippines. He teaches courses in environmental science and sustainable development studies. His researches are geared towards understanding diversity and environmental conservation (e-mail:ecadbs_csmmsuiit@ ahoo.com).

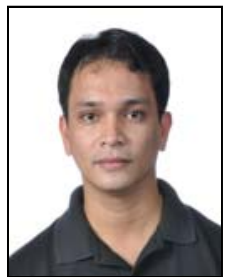

Mark Anthony J. Torres is Associate Professor of Biology of the Department of Biological Sciences, College of Science \& Mathematics, MSU-Iligan Institute of Technology, Iligan City, Philippines. He is an active researcher in biology and currently a director of the Institute for Peace and Development of MSU-IIT (e-mail:torres.markanthony@gmail.com).

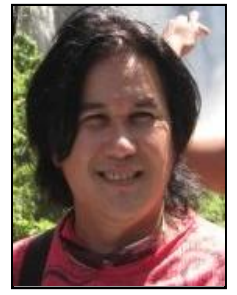

Cesar G. Demayo is the current chairman and Professor of the Department of Biological Sciences, College of Science and Mathematics, MSU-Iligan Institute of Technology, Iligan City, Philippines. His researches include environmental toxicology, biodiversity and genetics. He is an active member of the Philippine Society for the Study of Nature and the Pest Management Council of the Philippines. (e-mail: cgdemayo@gmail.com). 